\title{
ISOLATION AND PURIFICATION OF BACILLUS THURINGIENSIS VAR. ISRAELENSIS IMV B-7465 PEPTIDASE WITH SPECIFICITY TOWARD ELASTIN AND COLLAGEN
}

\author{
N. A. NIDIALKOVA ${ }^{1}$ L. D. VARBANETS ${ }^{1}$, V. O. CHERNYSHENKO \\ ${ }^{1}$ Institute of Microbiology and Virology, National Academy of Sciences of Ukraine, Kyiv; \\ e-mail:Nidialkova@gmail.com; \\ ${ }^{2}$ Palladin Institute of Biochemistry, National Academy of Sciences of Ukraine, Kyiv
}

\begin{abstract}
Peptidase of Bacillus thuringiensis var. israelensis IMV B-7465 was isolated from culture supernatant using consecutive fractionations by an ammonium sulphate (60\% saturation), ion-exchange chromatography and gel-filtration on the TSK-gels Toyoperl HW-55 and DEAE 650(M). Specific elastase (442 U.mg of protein ${ }^{-1}$ ) and collagenase (212.7 U.mg of protein ${ }^{-1}$ ) activities of the purified enzyme preparation were 8.0- and 6.1-fold, respectively higher than ones of the culture supernatant. Peptidase yields were $33.5 \%$ for elastase activity and $30.1 \%$ for collagenase activity. It was established that the enzyme is serine metal-dependent alkaline peptidase with $\mathrm{Mr}$ about $37 \mathrm{kDa}$. Maximal hydrolysis of elastin and collagen occurs at the optimum $\mathrm{pH} 8.0$ and $t^{\circ}-40$ and $50^{\circ} \mathrm{C}$, respectively. The purified preparation has high stability at $\mathrm{pH}$ in the range of 7.0 to 10.0 and $40-50^{\circ} \mathrm{C}$.
\end{abstract}

Key words: Bacillus thuringiensis, peptidase, elastase activity, collagenase activity, physicochemical properties.

I $\mathrm{t}$ is known that microbial peptidases are widely used in various industries such as pharmaceutical, food, leather, detergent [1]. It has been estimated that the annual sales of industrially produced enzymes is about $\$ 1$ billion, $75 \%$ of industrially produced enzymes are hydrolases, and among them $60 \%$ are peptidases, most of which (50\%) obtained from bacteria of genus Bacillus. The main countries producing peptidase are Denmark (40\%), the USA (20\%) and Italy (40\%).

Enzymes, which are capable of cleaving soluble proteins such as collagen and elastin, the components of connective tissue fibers, take a special place among peptidases of microorganisms. These proteins have firm and resistant to proteolysis structure owing to formation of intermolecular cross-linking. Peptidases with collagenase and elastase activities can be used in the development of drugs for trophic ulcers, pus wounds, burns, as well as in detergents to dissolve protein contaminants.

The peptidases are used in the food industry and for the manufacture of detergents, are isolated in plenty in crude state, but highly purified enzymes are necessary for medicine.

Despite significant progress in the researches on proteolytic enzymes, the needs of different sec- tors of Ukrainian production for preparations with varying degrees of specificity are not being met, especially in medicine and leather industries, which use imported enzymes, which often do not meet quality standards [2].

Previously, based on the screening of microorganisms of different taxonomic groups, we selected Bacillus thuringiensis var. israelensis IMV B-7465 strain which was active towards the insoluble protein substrates, such as collagen and elastin. Since such peptidases could be promising in the development of novel drugs aimed at hydrolysis of collagen and elastin, as well as in detergents for removing insoluble protein contaminants, the aim of our study was to isolate, purify and characterize peptidase of $B$. thuringiensis var. israelensis IMV B-7465 with collagenase (3.4.24.3) and elastase (3.4.21.11) activities.

\section{Materials and Methods}

The strain of Bacillus thuringiensis var. israelensis IMV B-7465, obtained from the water area of Snake Island (Black Sea) and kindly provided by the staff of the Department of Microbiology, Virology and Biotechnology of the Odessa I. I. Mechnikov National University, was the object of the study. The strain is registered as a producer of collagenase 
peptidase in the Depository of the Zabolotny Institute of Microbiology and Virology, NAS of Ukraine No. IMV B-7465.

To synthesize the extracellular peptidase, $B$. thuringiensis var. israelensis IMV B-7465 was cultivated on a liquid culture medium [3] consisting of $(\mathrm{g} / \mathrm{l}): \mathrm{KH}_{2} \mathrm{PO}_{4}$ - 1.6; $\mathrm{MgSO}_{4} \cdot 7 \mathrm{H}_{2} \mathrm{O}$ - 0.75; $\mathrm{ZnSO}_{4} \cdot 7 \mathrm{H}_{2} \mathrm{O}-0.25$; $\left(\mathrm{NH}_{4}\right)_{2} \mathrm{SO}_{4}-0.5$; maltose - 1.0; gelatin - 10.0; yeast autolysate - 0.15; pH 6.5-6.7. The culture was grown in Erlenmeyer flasks on a rocking platform at $250 \mathrm{rpm}$ at $28{ }^{\circ} \mathrm{C}$ for $24 \mathrm{~h}$. The inoculum was grown in an appropriate medium for $24 \mathrm{~h}$, and then was seeded in flasks at a density of $10^{5}-10^{6} \mathrm{CFU} / \mathrm{ml}$.

B. thuringiensis var. israelensis IMV B-7465 peptidase was isolated from the supernatant, obtained by centrifugation of the culture fluid at $5000 \mathrm{~g}$ for $30 \mathrm{~min}$, by ammonium sulfate (60\% saturation) precipitation. The precipitate was collected by centrifugation at $5000 \mathrm{~g}$, for $30 \mathrm{~min}$, dissolved in $0.01 \mathrm{M}$ Tris-HCl buffer (pH 7.5) and applied to a column $(2.5 \times 40 \mathrm{~cm})$ with anion exchanger TSK DEAE 650 (M) (Toyosoda, Japan). Elution was conducted with $0.01 \mathrm{M}$ Tris-HCl buffer ( $\mathrm{pH} 7.5$ ) in $\mathrm{NaCl}$ gradient from 0 to $1.0 \mathrm{M}$ at a flow rate of $0.5 \mathrm{ml} / \mathrm{min}$. Protein fractions which have collagenase and elastase activity were collected, combined and applied to a column $(1.8 \times 40 \mathrm{~cm})$ with neutral TSK-gel Toyopearl HW-55 (Toyosoda, Japan). Elution was carried out with the same buffer at a flow rate of $0.85 \mathrm{ml} / \mathrm{min}$. The degree of the enzyme purification was characterized by specific elastase and collagenase activity (U.mg of protein ${ }^{-1}$ ).

Protein content was measured at $280 \mathrm{~nm}$ using spectrophotometer SF-26 at all stages of the experiments. Protein concentration was determined by Lowry assay [4].

Total carbohydrate concentration was determined using phenol-sulfuric method [5]. For this, $0.5 \mathrm{ml}$ of the examined enzyme solution, $0.5 \mathrm{ml}$ of a $5 \%$ phenol solution and $2.5 \mathrm{ml}$ of concentrated sulfuric acid were mixed with intense stirring in tubes and incubated for $30 \mathrm{~min}$ at room temperature. Absorbance was measured at $490 \mathrm{~nm}$. The carbohydrate content was assessed by a standard curve for glucose.

For assessment of collagenase activity [6] the mixture containing $10 \mathrm{mg}$ of collagen, $2.5 \mathrm{ml}$ of $0.01 \mathrm{M}$ Tris-HCl buffer (pH 9.0-10.0) and $1 \mathrm{ml}$ of the studied preparation was incubated in a water bath at $37^{\circ} \mathrm{C}$ for $3 \mathrm{~h}$. The reaction mixture was then centrifuged at $10000 \mathrm{~g}$ for $5 \mathrm{~min}$ and $0.1 \mathrm{ml}$ of supernatant was transferred to tubes containing $0.5 \mathrm{ml}$ of $4 \%$ ninhydrin in acetone solution and an equal volume of $0.2 \mathrm{M}$ citrate buffer ( $\mathrm{pH}$ 5.0). Incubation was carried out in a boiling water bath for $20 \mathrm{~min}$. Then, $5 \mathrm{ml}$ of $50 \% \mathrm{n}$-propanol was added to the cooled mixture and kept at room temperature for additional $15 \mathrm{~min}$. The cleavage products were determined at $600 \mathrm{~nm}$ using SF-26 spectrophotometer. The equivalent amount of amino acids released during hydrolysis was determined from a standard curve for free L-leucine. One unit of the activity is equivalent to $1 \mu \mathrm{mol}$ of L-leucine released from collagen during hydrolysis for $3 \mathrm{~h}$ at $37^{\circ} \mathrm{C}$.

The basis of the method for determination of elastase activity is colorimetric measurement of the color intensity of a solution containing elastin-congo red as an enzyme substrate [7]. The mixture containing $2.0 \mathrm{ml}$ of $0.01 \mathrm{M}$ Tris-HCl buffer (pH 7.5), $5 \mathrm{mg}$ of elastin stained with $0.002 \%$ congo red and $1 \mathrm{ml}$ of enzyme solution was incubated at $37^{\circ} \mathrm{C}$ for $3 \mathrm{~h}$. The reaction was terminated by putting the tubes with the reaction mixture into an ice bath for $30 \mathrm{~min}$. Non-hydrolyzed elastin was separated by centrifugation at $10000 \mathrm{~g}$ for $5 \mathrm{~min}$. The color intensity was measured at $515 \mathrm{~nm}$ on SF-26 spectrophotometer. The amount of enzyme that catalyses hydrolysis of $1 \mathrm{mg}$ of elastin per $1 \mathrm{~min}$ was taken as the unit of activity.

SDS-PAGE under denaturing conditions was performed according to Laemmli [8]. For this, the studied enzyme preparation was dissolved in a sample buffer (0.5 M Tris-HCl, 2-mercaptoethanol (pH 8.8), 10\% SDS, 20\% glycerol and $0.001 \%$ bromophenol blue), boiled up and then applied to a gel (5-10 $\mu$ g per well). Electrophoresis was performed in $4 \%$ concentrating and $12 \%$ separating acrylamide gels at constant amperage $30 \mathrm{~mA}$. The enzyme was detected in the gel by staining with Coomassie G-250. The proteins Fermentas PageRuler ${ }^{\mathrm{TM}}$ Prestained Protein Ladder (SM0671) were used as comparative markers. Electrophoregrams were scanned. An increase in the color intensity of peptidase zone was examined using Totallab TL100 analysis software.

The effect of $\mathrm{pH}$ and temperature on the purified $B$. thuringiensis var. israelensis IMV B-7465 activity was studied in the temperature range from 20 to $80^{\circ} \mathrm{C}$ and $\mathrm{pH}$ range from 5.0 to 12.0 . Standard $0.01 \mathrm{M}$ phosphate buffer was used to obtain the $\mathrm{pH}$ range. To investigate stability, the enzyme was incu- 
bated in the buffer at $\mathrm{pH} 7.0-12.0$ and $40-60{ }^{\circ} \mathrm{C}$ for 0 , $15,30,60$ and $120 \mathrm{~min}$, then aliquots were taken to analyze collagenase and elastase activities.

Protein concentration in the peptidase preparation was $0.2 \mathrm{mg} / \mathrm{ml}$. The specific activity was expressed in U per mg of protein.

To study the effect of group-specific reagents on the enzyme activity we used the purified enzyme preparation and the following specific chemical reagents (final concentration $0.01 \mathrm{M}$ ): phenylmethylsulfonyl fluoride (PMSF), dithiothreitol (DTT), 1-ethyl3-[3-dimethylaminopropyl]carbodiimide (EDC), $p$-chloromercuribenzoate ( $p$-CMB), N-ethylmaleimid (NEM), ethylene glycol tetraacetic acid (EGTA), ethylene diamine tetraacetic acid (EDTA), disodium ethylenediaminetetraacetate (Trilon B), L-cysteine and soybean trypsin inhibitor. Incubations of the enzyme and reagents were performed at $15-20{ }^{\circ} \mathrm{C}$ for $60 \mathrm{~min}$, then aliquots were taken to determine enzyme activity.

To compare elastase activity of purified B. thuringiensis var. israelensis IMV B-7465 with commercial preparation, proteinase K (Merck, Germany) isolated from Tritirachium album was used. Protein concentration in both preparations was $0.2 \mathrm{mg} / \mathrm{ml}$.

All experiments were performed in 5-8 replicates. Statistical processing of the obtained data was performed using Student's $t$-test [9]. The data are presented as mean and standard error $(M \pm m)$. Processing of the data presented in graphs was performed using Microsoft Excel 2010 software. $P<0.05$ values were considered statistically significant [10].

\section{Results and Discussion}

Peptidase of $B$. thuringiensis var. israelensis IMV B-7465 was isolated using standard multistage purification procedure: ammonium sulfate fractionation (60\% saturation) of the culture supernatant, ionexchange chromatography and gel-filtration. It was shown (Fig. 1) when separating complex enzyme preparation by ion-exchange chromatography on TSK Toyopearl DEAE 650(M) column using a $\mathrm{NaCl}$ stepwise gradient from 0 to $1 \mathrm{M}$, that peptidase with collagenase and elastase activity eluted as one peak at $0.2 \mathrm{M} \mathrm{NaCl}$. It enabled to eliminate some protein

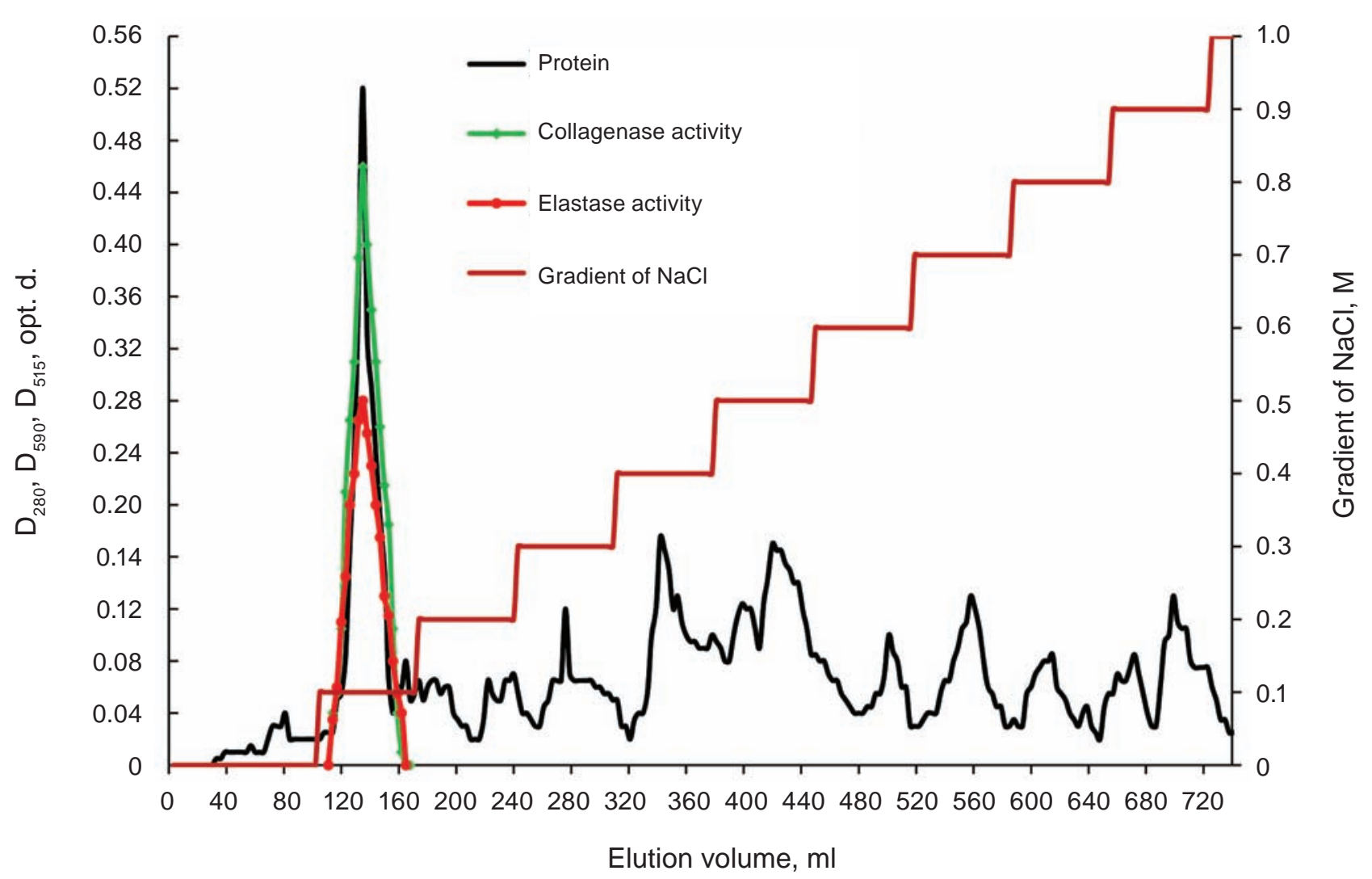

Fig. 1. The elution profile of the complex enzyme preparation of B. thuringiensis var. israelensis IMV B-7465 on TSK Toyopearl DEAE 650(M) with a NaCl stepwise gradient 


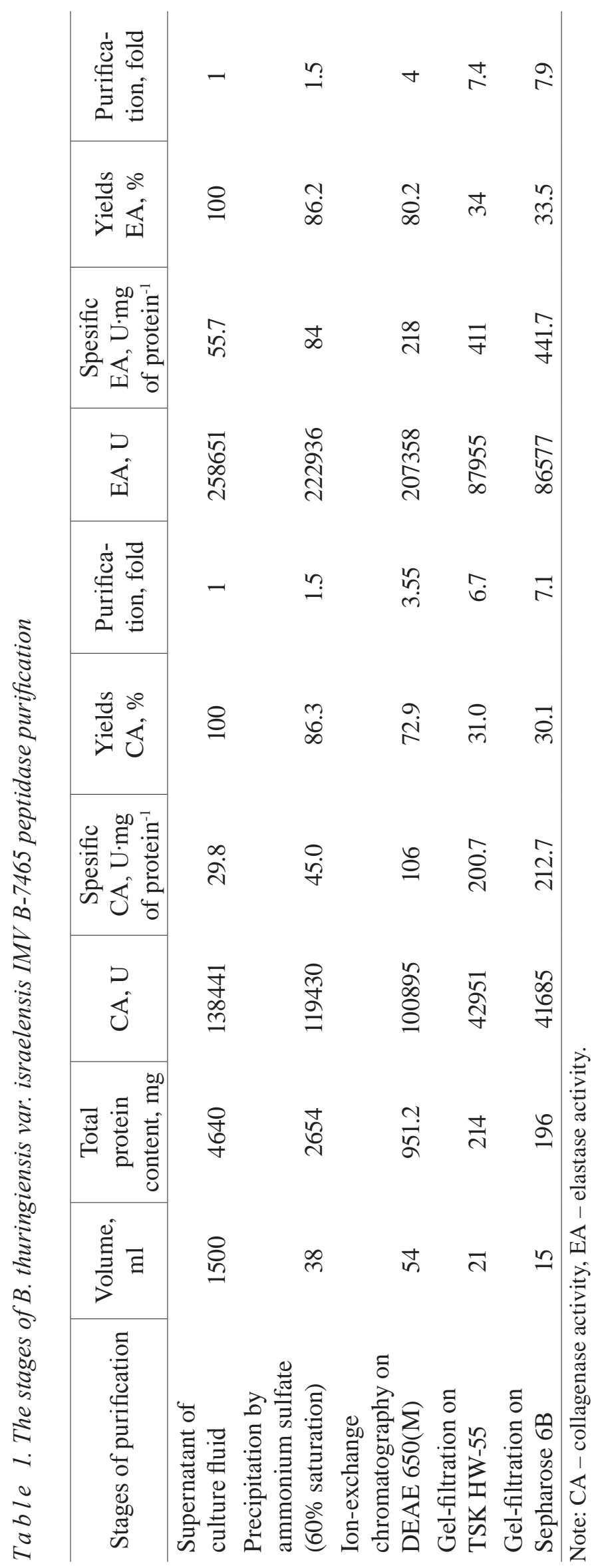


contaminants from the enzyme preparation. Thereat, collagenase and elastase activity increased 3- and 4-fold, respectively compared to the activity of the culture supernatant (Table 1).

The fraction with collagenase and elastase activities was further purified by gel-filtration on a TSK Toyopearl HW-55 column. It was established (Fig. 2) that elution with $0.01 \mathrm{M}$ Tris-HCl buffer ( $\mathrm{pH}$ 7.5) enabled to obtain the studied enzyme (peak 1) in one fraction. Purification degree was 5.7and 7.4-fold, respectively. Activities in the peaks 2 and 3 were not detected.

Fraction 1, which exhibited collagenase and elastase activity, was further purified by chromatography on Sepharose 6B (Pharmacia, Sweden) column $(1.5 \times 25 \mathrm{~cm})$ equilibrated with $0.01 \mathrm{M}$ Tris$\mathrm{HCl}$ buffer ( $\mathrm{pH}$ 7.5). As a result, only one peak with collagenase and elastase activity was detected (Fig. 3) that indicates homogeneity of the preparation obtained after the second stage of purification. The degree of purification was 6.1- and 8-fold, respectively (Table. 1).

The homogeneity of the studied enzyme of B. thuringiensis var. israelensis IMV B-7465 was also confirmed by SDS-PAGE under denaturing conditions (Fig. 4, $b$ ). The use of protein-markers in native (Sepharose 6B) (Fig. 4, $a$ ) and denaturing con- ditions (SDS-PAGE) enabled to determine that the peptidase $\mathrm{Mr}$ is about $37 \mathrm{kDa}$.

Since the enzyme homogeneity was shown by gel-filtration on Sepharose 6B and SDS-PAGE, we consider the $B$. thuringiensis var. israelensis IMV B-7465 peptidase as one enzyme that exhibits specificity for collagen and elastin proteins. Previously we obtained similar results for $B$. thuringiensis IMV B-7324, which synthesizes peptidase 1 with activity towards elastin and fibrin.

It is known that the members of genus Bacillus produce mainly peptidases with $\mathrm{Mr}$ from 15 to $100 \mathrm{kDa}$. $\mathrm{Mr}$ of bacilli elastases are from 20 to $30 \mathrm{kDa}$. Thus, the elastases with $\mathrm{Mr} 29.5 \mathrm{kDa}$ and $25 \mathrm{kDa}$ were isolated from $B$. licheniformis ZJUEL31410 and Bacillus sp. 6644, respectively $[11,12]$. Collagenases from $B$. megaterium NRC have Mr 25 and $28 \mathrm{kDa}$ [16], from B. cereus - have Mr 38-48 kDa [18, 19].

Elastase activity of the purified peptidase of B. thuringiensis var. israelensis IMV B-7465 was found to be 1.5-fold higher than activity of the commercial preparation of proteinase K (Merck, Germany), which was taken as a comparative enzyme.

A small amount of carbohydrates (7\%) was found in the composition of the B. thuringiensis var. israelensis IMV B-7465 peptidase.

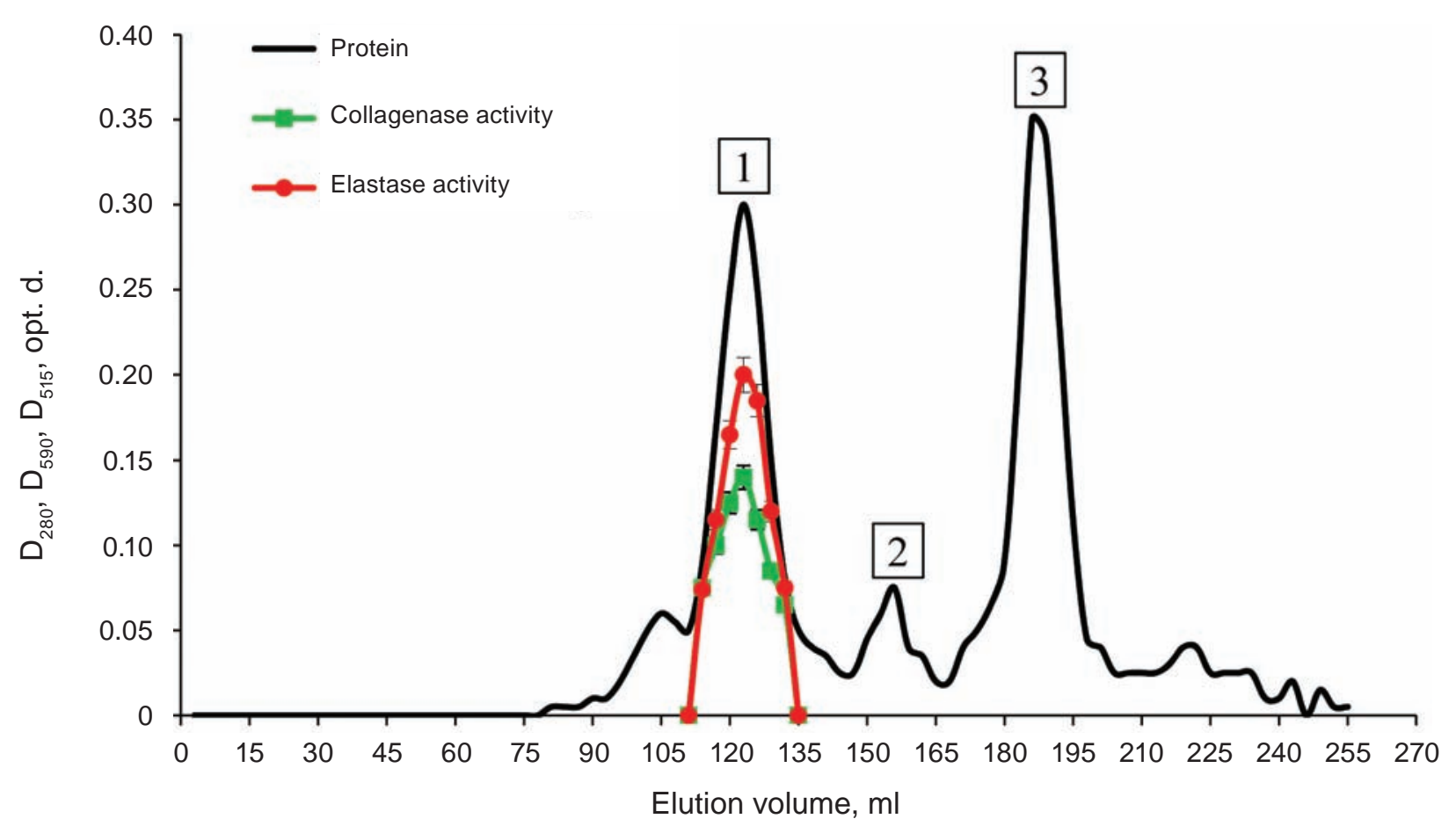

Fig. 2. The elution profile of B. thuringiensis var. israelensis IMV B-7465 fraction with collagenase and elastase activities on TSK Toyopearl HW-55 


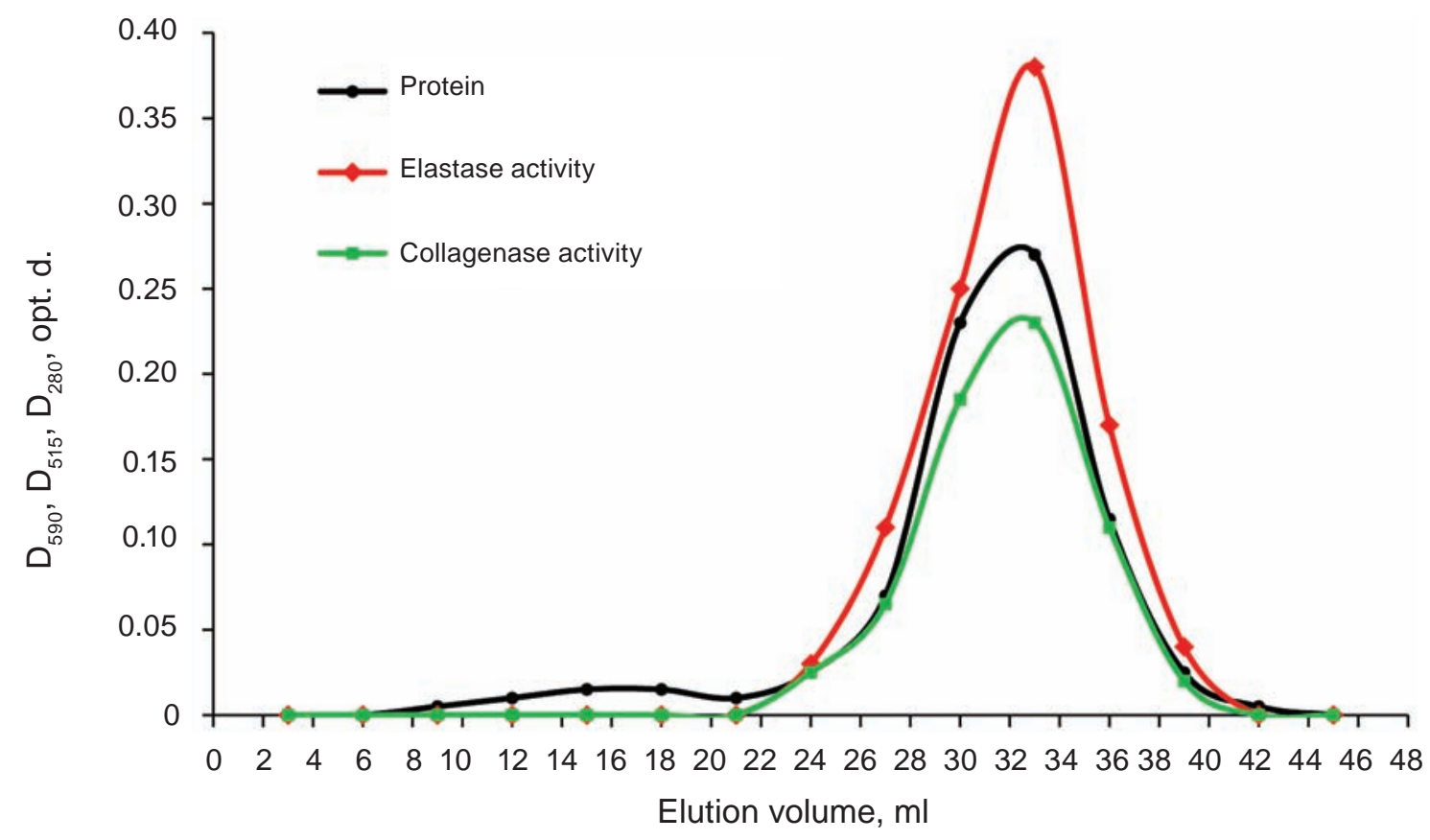

Fig. 3. The elution profile of peptidase B. thuringiensis var. israelensis IMV B-7465 on Sepharose $6 B$

a

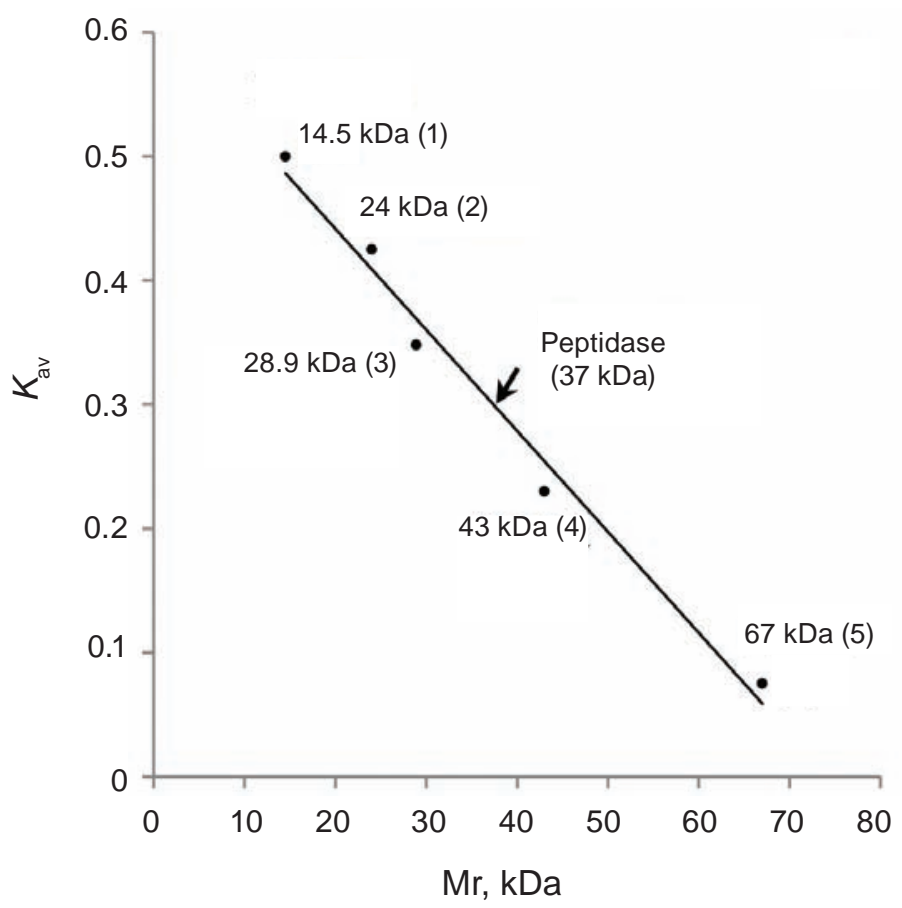

b

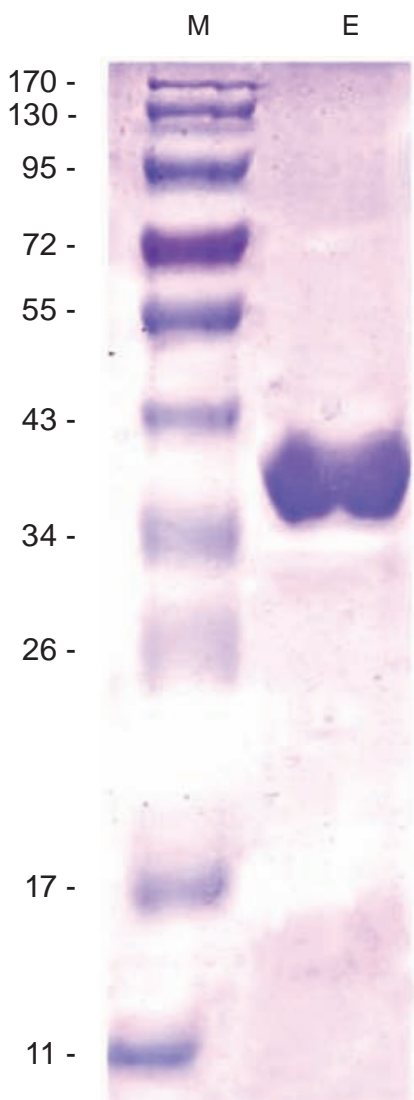

Fig. 4. Determination of $M r$ of B. thuringiensis var. israelensis IMV B-7465 peptidase under native (a) and denaturing (SDS-PAGE) (b) conditions: a - gel-filtration on Sepharose $6 B$ (calibration curve); $K_{a v}$ - distribution coefficient; protein-markers: lysozyme (1), trypsin (2), proteinase K (3), peroxidase (4), BSA (5); $b$ - SDSPAGE: $M$ - protein-markers; $E-B$. thuringiensis var. israelensis IMV B-7465 peptidase 
The optimum conditions, exactly $\mathrm{pH}$ and temperature ranges, at which enzymes retain their highest activity and stability are important characteristics of any enzyme preparations. Change of environmental conditions greatly affects the structure and function of enzymes that is an example of adaptation at the biochemical level. According to the literature, the majority of bacilli peptidases with collagenase and elastase activities is alkaline and works in the $\mathrm{pH}$ range from 5.0 to 11.0. It has been shown (Fig. 5) that the purified B. thuringiensis var. israelensis IMV B-7465 peptidase is active at $\mathrm{pH}$ range from 6.0 to 11.0. The $\mathrm{pH}$ optimum for collagen and elastin hydrolysis by the enzyme was 8.0 that indicates that the obtained enzyme is alkaline peptidase.

Investigation of the stability of $B$. thuringiensis var. israelensis IMV B-7465 peptidase showed that after $120 \mathrm{~min}$ in the $\mathrm{pH}$ range from 7.0 to 9.0, 80$90 \%$ of the initial collagenase and elastase activities were retained (Fig. 6). The increase in $\mathrm{pH}$ to 11.0 and 12.0 resulted in a decrease in both activities to $50-70 \%$.

The isolated enzyme was active in the temperature range from 30 to $60{ }^{\circ} \mathrm{C}$, at that optimum temperatures for hydrolysis of collagen and elastin by the peptidase were different: $50^{\circ} \mathrm{C}$ - for collagen and $40{ }^{\circ} \mathrm{C}$ - for elastin (Fig. 7).

The enzyme retained $100 \%$ of collagenase and elastase activities during incubation at 40, 50 and $60{ }^{\circ} \mathrm{C}$ for $30 \mathrm{~min}$. After incubation for $2 \mathrm{~h}$ at 40 and $50{ }^{\circ} \mathrm{C}, 90$ and $80 \%$ of the initial activities, respec- tively remained, whereas at $60{ }^{\circ} \mathrm{C}$ only $72 \%$ was remained (Fig. 8).

The differences in optimum conditions for interactions of enzyme with various substrates can be characterized by either mechanism of the enzymesubstrates binding or changes in the molecule conformation at various temperatures [13]. Our results are confirmed by the literature data showing that collagenase peptidases exhibit maximum activities at $\mathrm{pH} 7.0-8.0$ in the temperature range from 25 to $65{ }^{\circ} \mathrm{C}$. The highest activity of collagenase of B. stearothermophilus DPUA1729 reported to be at $\mathrm{pH} 7.2$ and $25{ }^{\circ} \mathrm{C}$ [14], B. megaterium NRC at $\mathrm{pH} 7.5$ and $50{ }^{\circ} \mathrm{C}$ [15], B. licheniformis $\mathrm{F} 11$ - at $\mathrm{pH} 9.0$ and $50^{\circ} \mathrm{C}$ [16], B. cereus MBL13 - at pH 8.0 and $40{ }^{\circ} \mathrm{C}$ [17], B. cereus AT - at pH 8.0 and $50^{\circ} \mathrm{C}$ [18]. As it is seen, the majority of bacilli elastases are alkaline enzymes. Optimum conditions for their actions are $\mathrm{pH}$ from 8.0 to 10.5 and temperature from $40^{\circ}$ to $65^{\circ} \mathrm{C}[11,19,20]$. However, among such elastases, neutral enzymes can be also found, e.g. B. licheniformis ZJUEL31410 [10].

Our findings, that $B$. thuringiensis var. israelensis IMV B-7465 peptidase exhibits sufficiently high stability at $40-60^{\circ} \mathrm{C}$ and alkaline $\mathrm{pH}$, are essential for the use of this preparation in leather industry and in detergent compositions.

It is known that elastase (3.4.21.11) and collagenase (3.4.24.3) bacilli enzymes are members of a class of serine or metallopeptidases [10, 17]. The study on the identification of the functional groups

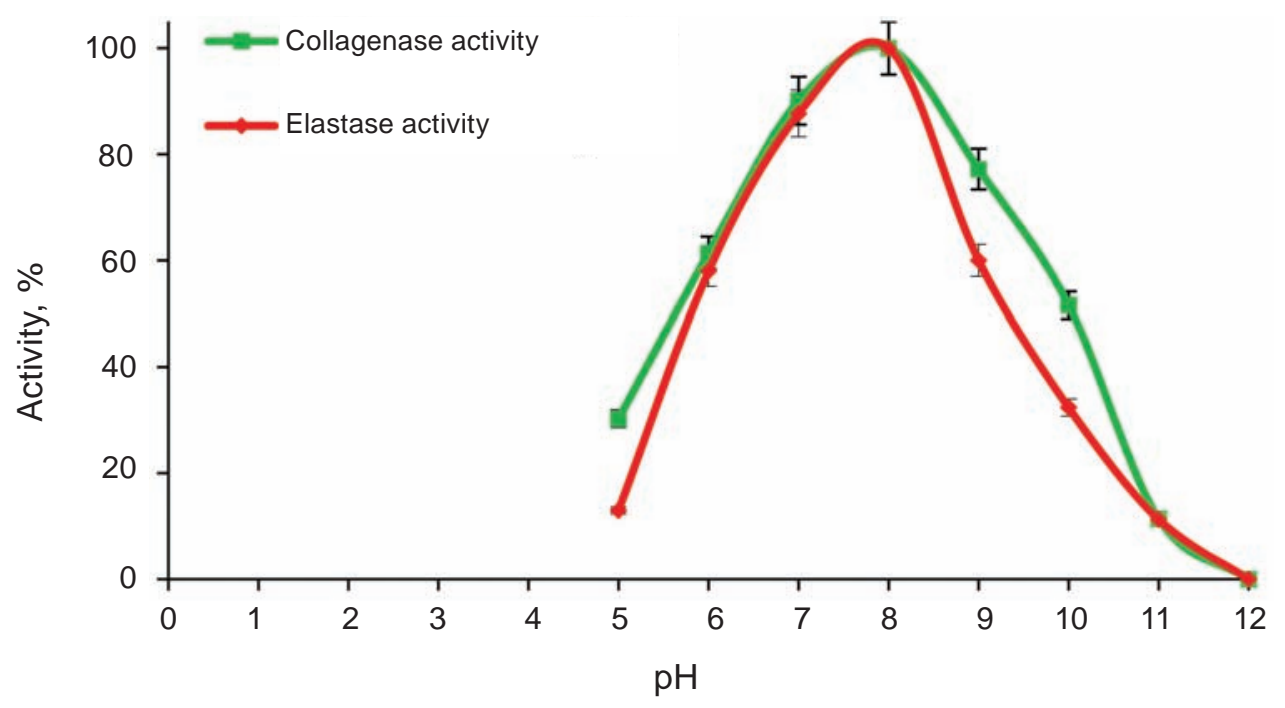

Fig. 5. The dependence of elastase and collagenase activity of B. thuringiensis var. israelensis IMV B-7465 peptidase on $\mathrm{pH}$ of reaction medium 
a

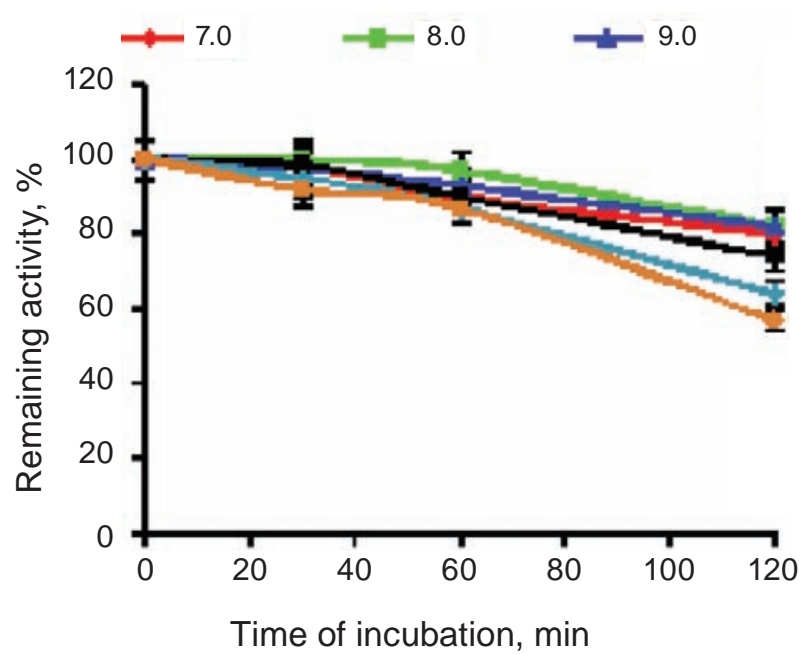

$\boldsymbol{b}$

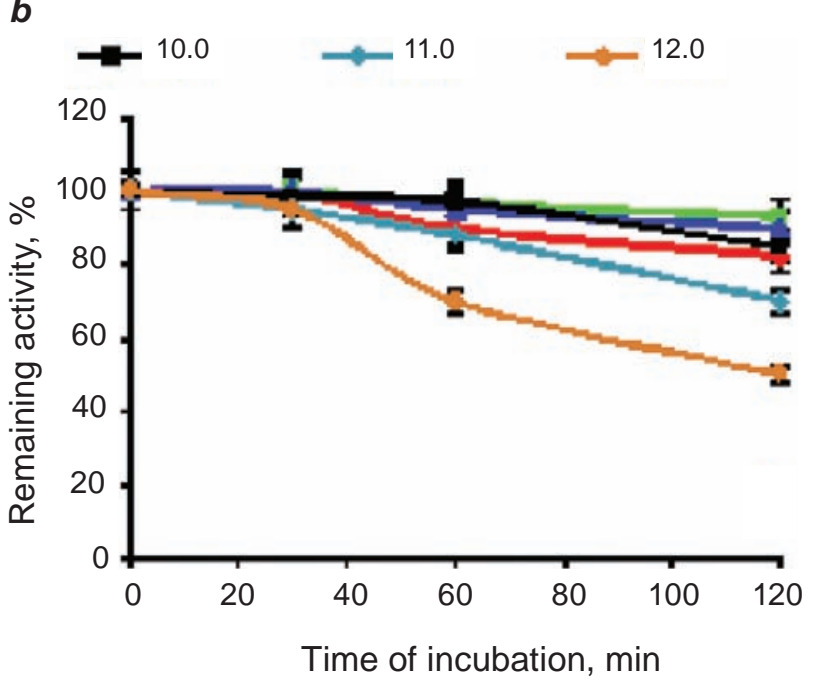

Fig. 6. The dependence of stability of B. thuringiensis var. israelensis IMV B-7465 peptidase on various pH at the hydrolysis of collagen (a) and elastin (b)

of the catalytic center of $B$. thuringiensis var. israelensis IMV B-7465 peptidase using group-specific reagents has shown (Fig. 9) that this peptidase belongs to serine peptidases, since a complete inhibition of its activity by PMSF was observed.

Since metallochelator EDTA caused the reduction in the activity by 3.7-fold compared to the control, it can be assumed that this enzyme is also metal-dependent. The inhibitory effect of p-CMB (13-fold) may indicate the presence of SH-groups on the surface of the enzyme molecule which are involved in the binding and hydrolysis of insoluble macromolecular protein substrates.

Thus, it has been shown that a strain of B. thuringiensis var. israelensis IMV B-7465 synthesizes peptidase with collagenase $(212.7 \mathrm{U} \cdot \mathrm{mg}$ of protein $^{-1}$ ) and elastase (442 U.mg of protein ${ }^{-1}$ ) activities, $\mathrm{Mr} \sim 37 \mathrm{kDa}$. Optimum conditions for its action are pH 8.0 and $40^{\circ} \mathrm{C}$ and $50{ }^{\circ} \mathrm{C}$, respectively, during elastin and collagen hydrolysis. The purified product

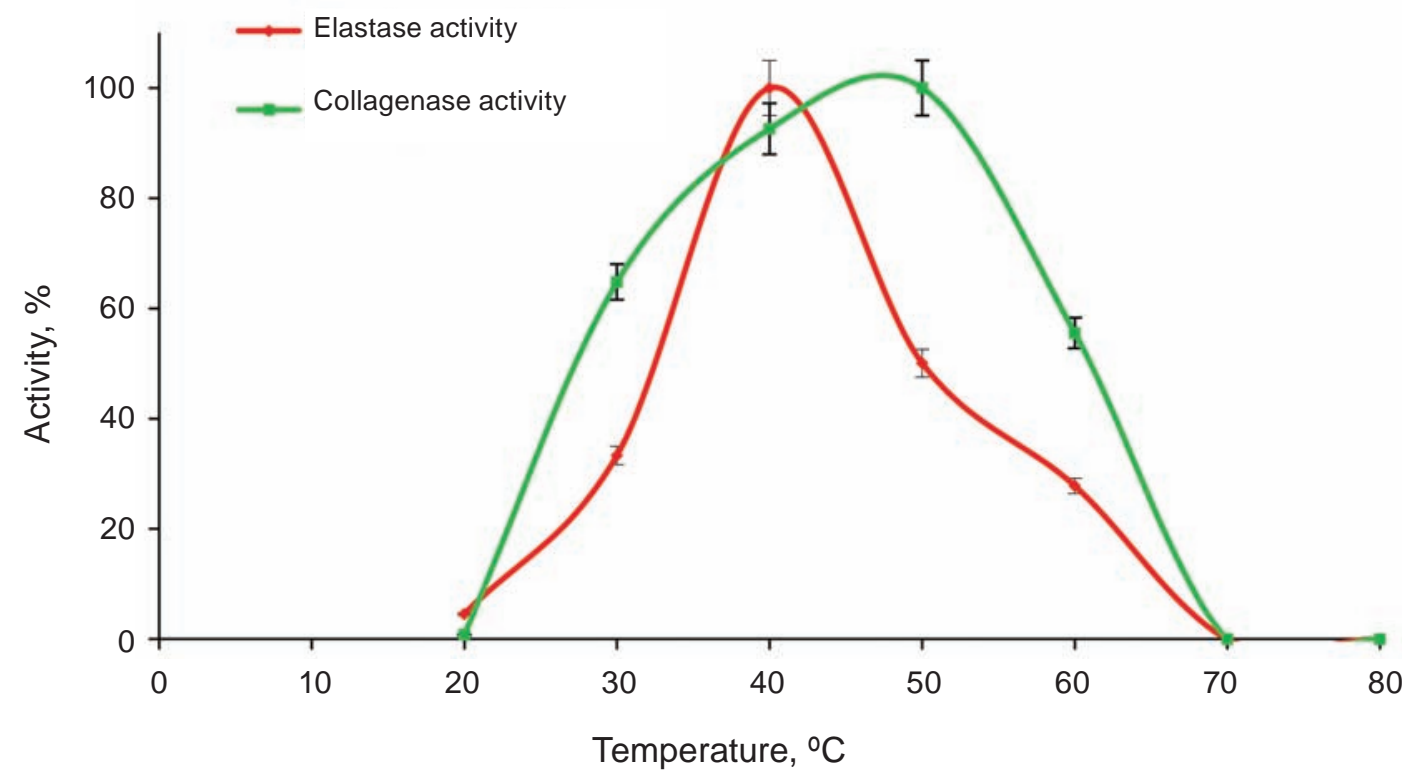

Fig. 7. The dependence of elastase and collagenase activity of B. thuringiensis var. israelensis IMV B-7465 peptidase on temperature of the reaction medium 
a

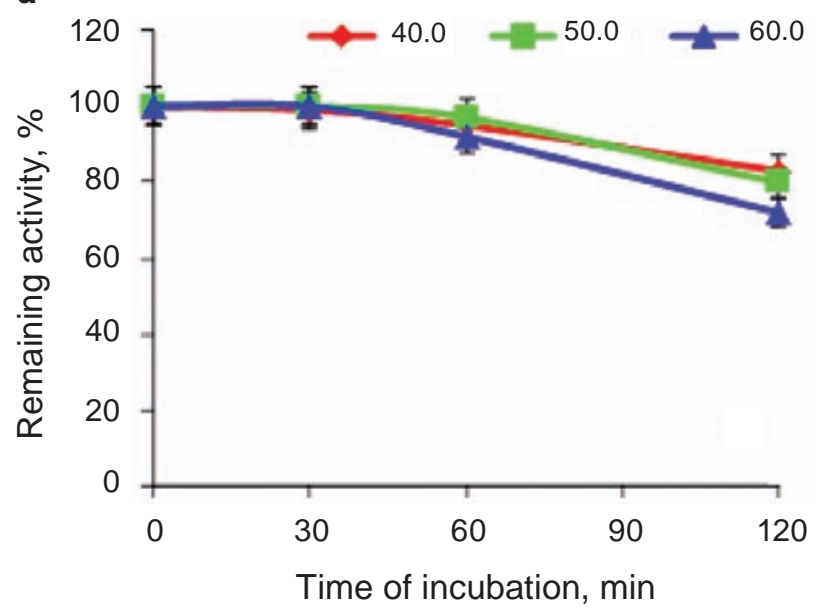

$\boldsymbol{b}$

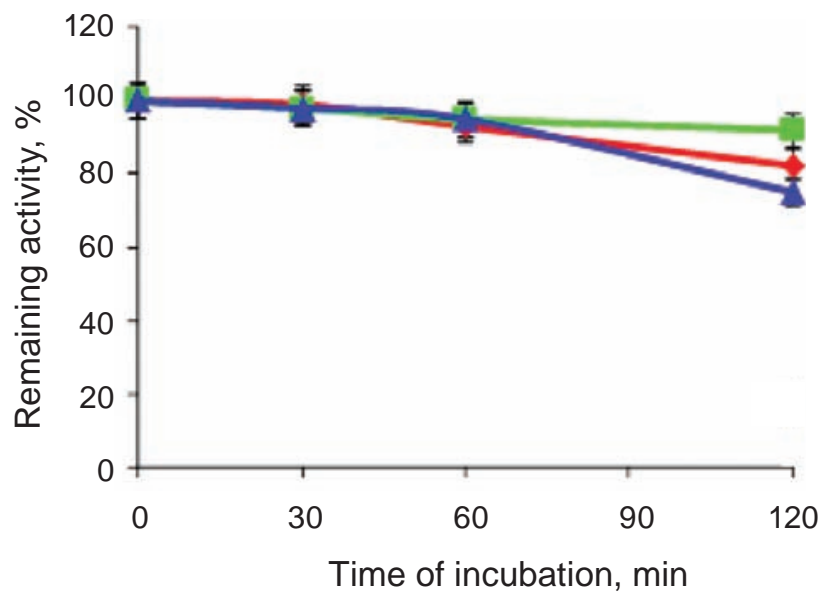

Fig. 8. The dependence of stability of B. thuringiensis var. israelensis IMV B-7465 peptidase on various temperatures at the hydrolysis of collagen (a) and elastin (b)

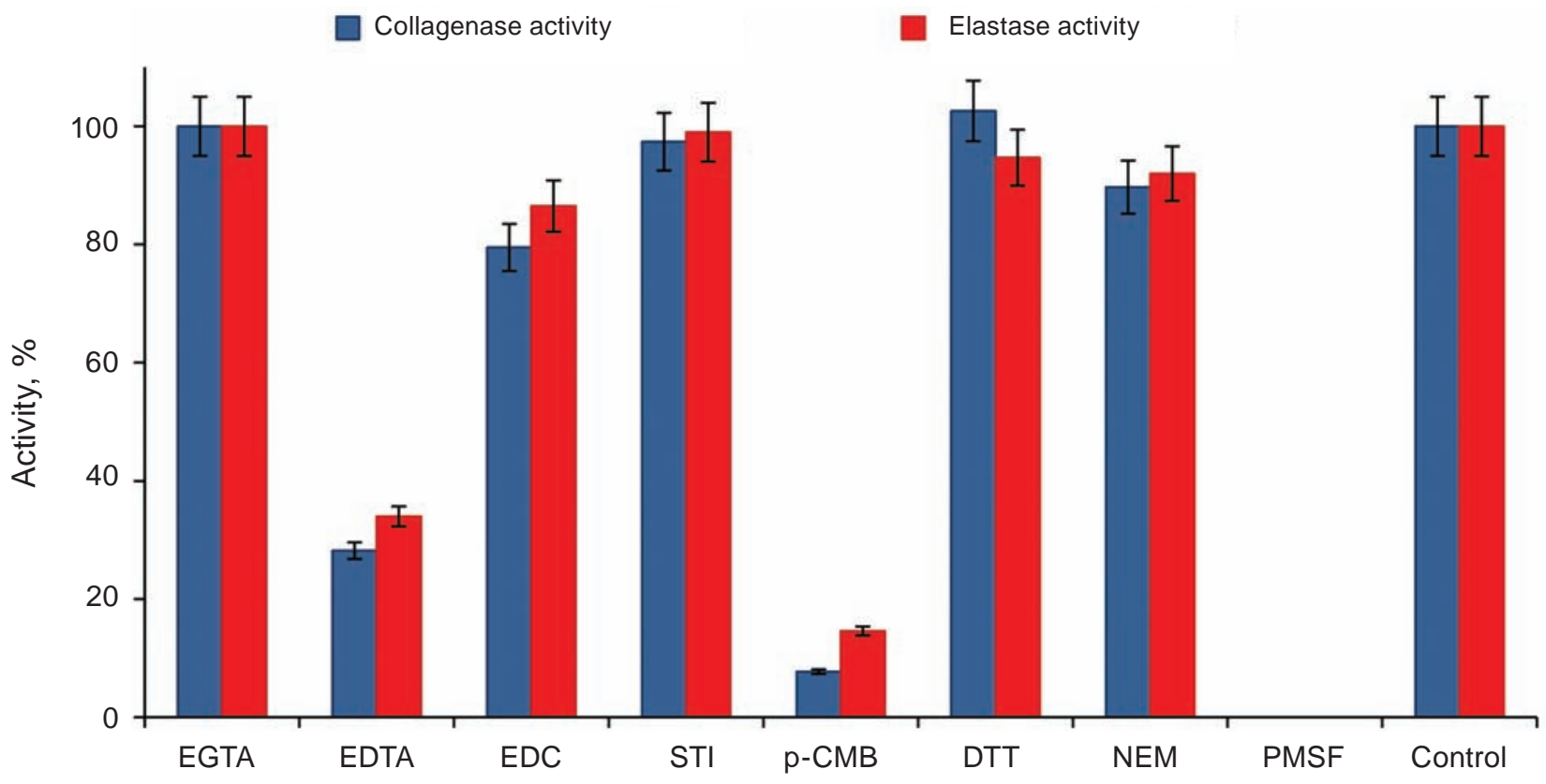

Group-specific reagents, $0.01 \mathrm{M}$

Fig. 9. The effect of group-specific reagents on the activity of B. thuringiensis var. israelensis IMV B-7465 peptidase

shows high stability at $\mathrm{pH} 7.0-10.0$ and $40-50{ }^{\circ} \mathrm{C}$. The investigation of functional groups of active site of B. thuringiensis var. israelensis IMV B-7465 peptidase with collagenase and elastase activities using inhibitory analysis indicates that this peptidase is metal-dependent serine peptidase with SH-groups on its surface. It has been shown that elastase activi- ty of B. thuringiensis var. israelensis IMV B-7465 peptidase is 1.5-fold higher than that of commercial product proteinase K (Merck, Germany), taken as a comparative enzyme.

\section{Acknowledgements}

We are grateful to the staff of the Department of Microbiology, Virology and Biotechnology of the 
Odessa I. I. Mechnikov National University for a kindly provided strain of $B$. thuringiensis var. israelensis IMV B-7465.

\section{ВИДІЛЕННЯ ТА ОЧИСТКА ПЕПТИДАЗИ ВАCILLUS THURINGIENSIS VAR. ISRAELENSIS IMВ В-7465 3І СПЕЦИФІЧНІСТЮ ДО ЕЛАСТИНУ І КОЛАГЕНУ}

\section{Н. А. Нідялкова ${ }^{1}$, Л. Д. Варбанеиь ${ }^{1}$, B. О. Чернишенко}

${ }^{1}$ Інститут мікробіології і вірусології ім. Д. К. Заболотного НАН України, Київ; e-mail: Nidialkova@gmail.com;

${ }^{2}$ Інститут біохімії ім. О. В. Палладіна НАН України, Київ

Пептидаза Bacillus thuringiensis var. israelensis IMB B-7465 виділена із супернатанта культуральної рідини методами послідовного фракціонування сульфатом амонію (60\% насичення), іонообмінної хроматографії та гельфільтрації на TSK-геля - Toyoperl HW-55 i DEAE

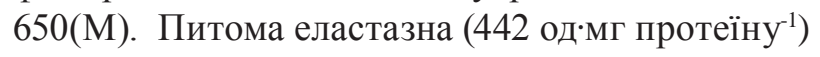
і колагеназна $\left(212,7\right.$ од·мг протеїну $\left.{ }^{-1}\right)$ активність очищеного ензимного препарату була відповідно в 8,0 і 6,1 раза вищою порівняно із супернатантом культуральної рідини. При цьому вихід пептидази за еластазною активністю сягав $33,5 \%$, за колагеназною - 30,1\%. Показано, що ензим $є$ сериновою металозалежною лужною пептидазою 3 Мм 37 кДа. Максимальний гідроліз еластину і колагену відбувається за оптимальних значень $\mathrm{pH}-8,0$ і температури -40 і $50{ }^{\circ} \mathrm{C}$ відповідно. Показано високу стабільність очищеного препарату у разі $\mathrm{pH}$ від 7,0 до $10,0 \mathrm{i} 40-50{ }^{\circ} \mathrm{C}$ протягом 2 годин.

Ключов і слова: Bacillus thuringiensis, пептидаза, еластазна активність, колагеназна активність, фізико-хімічні властивості.

\section{ВЫДЕЛЕНИЕ И ОЧИСТКА \\ ПЕПТИДАЗЫ ВАCILLUS \\ THURINGIENSIS VAR. ISRAELENSIS \\ ИМВ В-7465 СО СПЕЦИФИЧНОСТЬЮ К ЭЛАСТИНУ И КОЛЛАГЕНУ}

\author{
Н. А. Нидялкова ${ }^{1}$, Л. Д. Варбанеи ${ }^{1}$, \\ B. А. Чернышенко ${ }^{2}$
}

${ }^{1}$ Институт микробиологии и вирусологии им. Д. К. Заболотного НАН Украины, Киев; e-mail: Nidialkova@gmail.com;

${ }^{2}$ Институт биохимии им. А. В. Палладина НАН Украины, Киев

Пептидаза Bacillus thuringiensis var. israelensis ИМВ В-7465 выделена из супернатанта культуральной жидкости методами последовательного фракционирования сульфатом аммония (60\% насыщения), ионообменной хроматографии и гель-фильтрации на TSKгелях - Toyoperl HW-55 и DEAE 650(М). Эластазная (442 ед-мг протеина $\left.{ }^{-1}\right)$ и коллагеназная (212,7 ед·мг протеина $\left.{ }^{-1}\right)$ активность очищенного энзимного препарата была соответственно в 8,0 и 6,1 раза выше по сравнению с супернатантом культуральной жидкости. При этом выход пептидазы по эластазной активности достигал $33,5 \%$, по коллагеназной $-30,1 \%$. Показано, что энзим является сериновой металлозависимой щелочной пептидазой с Мм 37 кДа. Максимальный гидролиз эластина и коллагена происходит при оптимальных значениях $\mathrm{pH}-8,0$ и температуре - 40 и $50{ }^{\circ} \mathrm{C}$ соответственно. Показана высокая стабильность очищенного препарата при $\mathrm{pH}$ от 7,0 до 10,0 и $40-50{ }^{\circ} \mathrm{C}$ в течение 2 часов.

К л ю че вы е с ло в а:Bacillus thuringiensis, пептидаза, эластазная активность, коллагеназная активность, физико-химические свойства. 


\section{References}

1. Furhan J, Sharma S. Microbial alkaline proteases: findings and applications. Int J Inv Pharm Sci. 2014; 2(4): 823-834.

2. Varbanets LD, Matseliukh EV. Peptidases of microorganisms and methods of their investigations. K.: Naukova dumka, 2014. 323 p. (In Russian).

3. Koltukova NV, Vaskivniuk VT. Selection of methods for the isolation of the proteolytic complex from Bacillus mesentericus $316 \mathrm{~m}$ at deep cultivation. Microbiol. Zhurn. 1980; 42(2): 245-248. (In Russian)

4. Lowry OH, Rosebrough NJ, Farr AL, Randall RJ. Protein measurement with the Folin phenol reagent. J Biol Chem. 1951; 193(1): 265-275.

5. Dubois M, Gilles KA, Hamilton JK. Colorimetric method for determination of sugars and related substances. Anal Chem. 1956; 28(3): 350-356.

6. Mandl I. Collagenase. Science. 1970; 169(3951): 1234-1238.

7. Laemmli UK. Cleavage of structural proteins during the assembly of the head of bacteriophage T4. Nature. 1970; 227(5259): 680-685.

8. Trowbridge JO, Moon HD. Purification of human elastase. Proc Soc Exp Biol Med. 1972; 141(3): 928-931.

9. Lakin GF. Biometry. M.: High school, 1990. 352 p. (In Russian).

10. Lapatch SN, Tchubenko AV, Babitch PH. Statistical methods in biomedical research using “Excel”. K.: Morion, 2001. 408 p. (In Russian).

11. Chen QH, Ming-Liang FU, Xiao-Jie LIU. Purification and characteristics of elastase produced by Bacillus licheniformis. Food Sci. 2011; 32(7): 216-219.

12. Durham DR. The elastolytic properties of subtilisin GX from alkalophilic Bacillus sp. strain 6644 provides a means of differentiation from other subtilisins. Biochem Biophys Res Commun. 1993; 194(3): 1365-1370.
13. McGowan LC, Hamelberg D. Conformational plasticity of an enzyme during catalysis: intricate coupling between cyclophilin A dynamics and substrate turnover. Biophys J. 2013; 104(1): 216226.

14. Lima LA, Cruz Filho RF, dos Santos JG, Silva WC. Produção de protease colagenolítica por Bacillus stearothermophillus de solo amazônico. Acta Amaz. [online]. 2014; 44(4): 403-410.

15. Asker MM, Mahmoud MG, El Shebwy K, Abd el Aziz MS. Purification and characterization of two thermostable protease fractions from Bacillus megaterium. J Gen Eng Biotech. 2013; 11(2); 103-109.

16. Baehaki A, Sukarno, Syah D, Setyahadi S, Suhartono MT. Production and characterization of collagenolytic protease from Bacillus licheniformis F11.4 originated from Indonesia. Asian J Chem. 2014; 26(10): 2861-2864.

17. Liu L, Ma M, Cai Z, Yang X, Wang W. Purification and properties of a collagenolytic protease produced by Bacillus cereus MBL13 strain. Food Technol. Biotechnol. 2010; 48(2): 151-160.

18. Vijayaraghavan P, Lazarus S, Vincent SG. Dehairing protease production by an isolated Bacillus cereus strain AT under solid-state fermentation using cow dung: Biosynthesis and properties. Saudi J Biol Sci. 2014; 21(1): 27-34.

19. Matseliukh OV, Levishko AS, Varbanets LD. Proteolytic enzymes of microorganisms. Microbiol Zhurn. 2010; 72(4): 56-73. (In Ukrainian).

20. Muramatsu K, Yamawake N, Yoshimi T, Kanai Y, Kimura Y, Kiuchi K. Purification and Crystallization of a New Bacillus subtilis Elastase. J Home Economics Jap. 2000; 51(12): 1127-1135. 